ISSN 2414-1143

Научный альманах стран Причерноморья. 2018. Том 15. № 3

DOI 10.23947/2414-1143-2018-15-3-65-69

UDC $001+008+37$

\title{
THE REGIONAL PROBLEMS IN THE SPHERE OF SCIENCE, CULTURE AND EDUCATION
}

\author{
(C) Yuri A. Zhdanov
}

\begin{abstract}
Yuri A. Zhdanov - Doctor of chemistry, candidate of philosophical sciences, professor. Rector of the Rostov state university (1957-1988 22.).

Жданов Юрий Андреевич - доктор химических наук, кандидат фрилософрских наук, профрессор. Ректор Ростовского государственного университета (1957-1988 г2.).
\end{abstract}

The necessity of cooperation of natural and technical and humanitarian intellectuals of higher education institutions and scientific institutions of the North Caucasus and also of workers of culture does not require substantiation. Stabilization of the situation in the region is possible without it.

Such cooperation has to cover not only the region of the North Caucasus, but also related with it by natural and historical bonds all the Caucasus, Armenia, Georgia, Azerbaijan and also Ukraine and Kazakhstan, first of all. The clerisy is called to bring the knowledge, the spirit of benevolence and business cooperation to the wide class of workers, to interact with structures of the power, pointing at the pressing issues, preventing wrong actions.

Stability can be understood as process, movement and development. At the same time the emergence of these or those forms, sites of destabilization is quite natural. Stability inevitably includes changes and destabilization. At the same time it is important to prevent catastrophic processes and irreversible destructive consequences.

According to the International community in the modern world the following factors of instability are dangerous: ecological crisis; depletion of natural resources; illiteracy and low level of general scientific knowledge in all countries; the gap between rich and poor countries, regions, social groups; rivalry of elite in struggle for mastery, privileges; national extremism, spread of violence and terrorism. The higher school can influence on all these factors directly or indirectly.

The general higher education program is necessary. It would study instability factors in relation to each region. Besides, this program would reveal the nature and essence of spontaneous processes and determine the controlling parameters.

Modern social, political and economic development in the country and in the region has a contradictory character. It also relates to the sphere of science, education and culture. It is not only about reduction of appropriations. In the conditions of weakening of the central power and of the nation-wide beginning, the attention to the sphere of science, education and culture fell considerably and dangerously. On the other hand, in regions in the conditions of growth of sovereignties the independence of institutions in the specified sphere became stronger. The non-state education appeared. Such independence in many respects untied an initiative of collectives, expanded their external contacts, including international. 
The formation of local isolation and the threat of provincialism are the dangerous parts of sovereignization process. It is resisted by the global climate defining nowadays the general field of science, education, humanistic values. In the North Caucasus, there is a tendency of the organization of regional structures at the macrolevel (Rostov, Krasnodar, Nalchik, Stavropol, Vladikavkaz, and Makhachkala).

Reasonable regional policy is a factor which is called to play a crucial role. This obvious thesis needs specification as ordinary consciousness attributes to it various different meanings. Quite often regional policy is reduced to the center policy in relation to the separate administrative units on the periphery of Russia.

There was rather steady stereotype according to which the statehood is identified with centralism moreover with bureaucratic centralism. It is obvious that the state beginning includes centralism, but does not come down to it. The state interest can act at any regional and local level. Moreover, the self-interest in the center can be a carrier of private interest, but not of state one.

Strictly speaking, the regional policy should be determined both by its object and by its subject. In the exact sense of the word the regional policy belongs to the difficult integrated objects: Urals, Primorye, Central Black Earth Region, mid-Volga Region, North Caucasus and so forth. It is obvious that each of the regions represents some natural and geographical, economic, cultural and historical integrity. Its borders are obvious to the North Caucasus: Greater Caucasus Mountain Range in the South, the Caspian in the East, and the Azov and Black Sea basin in the West, Central Black Earth Region in the North. At the same time provinces, regions, republics act only as region subsystems.

The subjects of regional policy are central power, administrative structures in Moscow, ministries and departments. At the level of the region the structures of common regional significance: association of economic and social cooperation of heads of administrations, management of the North Caucasian railroad, command of the North Caucasus Military District, North Caucasian scientific center of the higher school, Union of the small cities, etc. function. Nowadays numerous specialized structures are formed. They are the Southern office of the International academy of Sciences of higher school (Krasnodar) on the basis of the Kuban State University; constellations of regional representative offices of separate firms, banks and higher education institutions.

Thus, the Taganrog radio engineering university created network of the educational centers in Rostov, Pyatigorsk, Kropotkin, Georgiyevsk, Volgodonsk, Elista.

Dagestan State Technical University carries out integration work through the Center of support of small business in science and through the Southern Russian office of Academy of technological sciences. The center of grants for agricultural mechanical engineering is created at Dagestan State Technical University.

Rostov State Economic Academy and Novosibirsk State Technical University pursue an active regional policy.

\section{Preservation of fundamental science sphere}

Modern reformers quite often say that the westernization of the country includes an approach to the post-industrial society. But such society is based on the highest technologies, the latest science that is unsuitable for the process of deindustrialization, descientization (from the word "scientism") and de-urbanization. The basis of post-industrial society is basic scientific researches and high general education level of population.

During the initial stage of the formation the North Caucasian scientific center laid the foundation of basic researches in the region. Institute of mechanics and applied mathematics, Institute of physical and organic chemistry, Institute of neurocybernetics, Institute of physics, 
Institute of economic and social problems were organized. Institute of geochemistry of landscapes was created in Novorossiysk later. At last, Institute of the Caucasus was created in the structure of the North Caucasian scientific center of higher school.

The magazine "News of Higher Educational Institutions. The North Caucasus region" and information letter are issued. There is a new magazine "Scientific thought of Caucasus", the publishing house is founded. The problem and branch laboratories were created in higher education institutions with the help of the North Caucasian scientific center of higher school. We will organize activity of specialized councils of State Commission for Academic Degrees and Titles.

The activity of numerous, newly created academies of Sciences is coordinated within the Academic Association at the North Caucasian scientific center of higher school.

The task is to keep the reached level of fundamental studies and to develop it according to the tendencies of the world science.

For concentration of efforts and means the more resolute distribution of work and coordination of activity of all regional scientific institutions, including Russian Academy of Sciences are necessary. Russian Academy of Sciences has its centers in Dagestan and Gelendzhik, including an astrophysical complex, unique for Europe. Nowadays dozens of members of Russian Academy of Sciences work in the region. Unfortunately, distracted by the problems, Russian Academy of Sciences pays insufficient attention to the North Caucasus though in 1930 the general meeting of Academy of Sciences of the USSR made the decision on the organization of its office in Rostov.

\section{Cooperation in studying and development of productive forces}

Higher education institutions of the North Caucasus under the coordinating conditions of the North Caucasian scientific center of higher school gained experience of research of production forces of the region. The multivolume work "Natural Resources and Productive Forces of the North Caucasus" covering all its riches from mineral to demographic was published.

The development programs of productive forces approved in the state order were developed for a number of territories (Chechen-Ingushetia, North Ossetia, the Rostov region).

Nowadays by request of Association of social and economic cooperation of provinces, regions and republics of the North Caucasus under the leadership of employees of the North Caucasian scientific center of higher school "The general program of social and economic development of the North Caucasus" is developed (1994).

At the request of administration of Kuban we participated in the development of the program of social and economic development of Krasnodar Krai.

Higher educational institutions within the regional programs could take an active part in studying of problems of demographic shifts, economic reforms, sociological situation, natural wealth, ecology and recreational opportunities.

Instead of addressing with our problems to the head councils in the mid-Volga Region or in the North-West it would be correct to create expert councils for examination of projects and programs of the region at the North Caucasian scientific center of higher school.

\section{Science and educational process}

Since the beginning of the formation, relying on intellectual potential of higher education institutions, the North Caucasian scientific center of higher school directed its efforts to the improvement of the higher education. With its assistance the main scientific directions of Dagestan University, Kalmyk University and higher education institutions of a technical profile were developed. It helped the condition of the higher school in the region. 
Relying on this experience, the North Caucasian scientific center of higher school could cope with an order of State Committee of the Russian Federation for Higher Education and become its regional office for the scientific methodological support of the state educational standard.

In new conditions it is necessary to continue the following begun work.

1. To determine the main directions of scientific research for recent universities and academies of nonclassical profile by forces of scientists of the region.

2. To strengthen general scientific, general-theoretical preparation in higher education institutions of all types, but first of all, in nonclassical, having developed and having founded the course "Modern Scientific Picture of the World" for all listeners.

3. To develop the course "Sustainable Development and Future of Mankind" for all listeners, taking into account the tendencies of the world development, the efforts of international organizations (conferences in Rio de Janeiro, Cairo, Copenhagen, etc.) directed to the achievement of sustainable development of society, to overcoming ecological and other critical phenomena.

4. To form the high culture of thinking on the basis of rationalistic traditions of history of human thought and knowledge.

\section{Researches in the sphere of humanitarian knowledge}

In previous years the fundamental work "History of Peoples of the North Caucasus" is prepared by forces of Caucasus scientists and Moscow historians. Two volumes were issued; the third volume was in manuscript. In addition to this work the edition of documentary collections of history of the North Caucasus was begun; the volume "The North Caucasus in Evidences of Antique Authors" and the collection of peasantry history were published.

The circumstances interrupted the begun work; there is a sense to continue it.

It is necessary to start developing of the little-investigated problem "The role of Caucasus in national history". It is also necessary to start preparing scientific work about the history of the Don, Kuban and Terek Cossacks and the reference work "Diasporas in the North Caucasus" with the help of joint efforts of scientists of the Caucasus.

\section{Cultural synthesis}

Within the North Caucasian scientific center of higher school the pioneering researches in the field of the theory and cultural history were developed. This problematic needs the deepening and the expansion. First of all it is necessary to mark the key problems.

1. The Caucasus is as a bridge between civilizations of the West and the East. Special attention should be paid on common features of the Alpine and Himalayan natural and geographical and ethno historical cultural belt in the sphere of housekeeping, life and culture. Such program (Tesis) can be carried out within the International academy of the higher school.

2. Synthesis of the Western and the Eastern Renaissance. It is necessary to overcome Eurocentric view on the Renaissance and to comprehend its east component more deeply. The Eastern Renaissance, like the Western Renaissance, relied on the traditions of ancient culture (Aristotelism, Platonism and Neoplatonism of many eastern thinkers and poets). Such names as Rudaki, Ferdowsi, Omar Khayyam, Rustaveli, Petritsi, David, Al-Biruni, Al Farabi, Ibn Khaldun, Saadi, Rumi, Jami, Ibn Tufail, Al-Ghazali and many others mark a wide spread of the Eastern Renaissance. In their works the aspiration of the personality to freedom, justice, knowledge and intelligence was reflected.

The modern science overcame unilateral European views in many respects, in particular, of the Renaissance problem. The concept of the Eastern Renaissance is proved by the works 
of such researchers as I. Krachkovsky, N. Konrad, I. Braginskii (Russia), Sh. Nutsubidze (Georgia), V. Chaloian (Armenia), P. Mets (Switzerland) and others. It is important to continue this direction in our country.

3. Cultural and civilization interactions in the North Caucasus. The role of international and interprofessional influences. Intermediary influence of diasporas (Greek, Armenian, Ukrainian, European and others). Inheritance of Hellenism, Iran, India, Turan, Byzantium in the culture of the North Caucasus.

The value of universities in formation of cultures polycentrism. Social function of intellectual elite.

4. The role of the Caucasus in cultural development of Russia. The Caucasus influenced the Russian culture decisively. It found reflection in folk art, folklore of the Don, Kuban, Terek cossacks, in formation of such surprising phenomenon as the Russian-Caucasian song. The Russian literature derived images and plots in the Caucasus. Let's remember Pushkin, Lermontov, Tolstoy, Bryusov, Mayakovsky, Yesenin. Glinka, Borodin, Balakirev, RimskyKorsakov's musical creativity and Yaroshenko, Vereshchagin's art creativity are connected with the Caucasus.

Many cultural workers of the Caucasus made an invaluable contribution to the Russian culture (Rustaveli, Isahakyan, Tumanyan, Zakharov, Gamzatov, Khetagurov, Esambayev, Temirkanov, Dudarova, Kuliyev, Stalsky, Keshokov, Tovstonogov, Chabukiani, etc.). The modern young intellectual has to know about it.

5. The North Caucasus peoples had a rich epos the anthology of which should be published, since Old Iranian "Avesta", including "Nart sagas", heroic and epic songs of Chechens "Illi", epic of "Janggar".

6. To organize the governmental "fund of assistance to the culture in the North Caucasus" for encouragement of scientific developments in the field of culture, the international relations, the growth of young workers.

7. To prepare and publish the reference book "Who Is Who in the North Caucasus" about scientists and cultures.

8. To develop at the universities of classical type the training of specialists in the field of Caucasus studies, and at Pyatigorsk State Linguistic University the training of specialists in the field of the East languages.

9. To create for the humanitarian intellectuals according to the tradition of Goethe and Pushkin the creative club and the collection "West-Eastern Divan".

10. To begin preparation in higher education institutions on the subject "Pushkin and Caucasus" in connection with the coming anniversary of the great poet.

11. It is necessary to create an information field of science in the region, using the network of libraries and e-mail.

Опубликовано на русском языке в издании: Известия высших учебных заведений. СевероКавказский регион. Общественные науки. 1996. № 2. С. 34-37

На английском языке публикуется впервые.

The article is published in Russian in the edition: The bulletin of higher educational institutions. The North Caucasus region. Social sciences. 1996. No. 2. pp. 34-37.

In English it is published for the first time.

August 30, 2018 